\title{
Release of enzymes from human leucocytes during incubation with Neisseria gonorrhoeae
}

\author{
LEAH MORFORD SENFF AND WILLIAM D. SAWYER \\ From the Department of Microbiology, Indiana University School of Medicine, Indianapolis, Indiana
}

SUMmARY The effect of Neisseria gonorrhoeae on release of enzymes from human leucocytes was determined. Supernatants from incubation mixtures containing leucocytes and gonococci were assayed for activity of the cytoplasmic enzyme, lactic acid dehydrogenase, as well as for activity of the hydrolytic enzymes, $\beta$-glucuronidase and lysozyme, which are found primarily in leucocyte granules. Thirty-minute incubation of leucocytes with pilated T1 gonococci resulted in a negligible release of lactic acid dehydrogenase and little release of $\beta$-glucuronidase even at bacteria to leucocyte ratios as high as 50 to 1 . Lysozyme release, however, was significant at this ratio and at 20 to 1 but not at 5 to 1 . Incubation with non-pilated T4 bacteria yielded no significant release of lactic acid dehydrogenase or $\beta$-glucuronidase, but it caused a significant release of lysozyme at bacteria to leucocyte ratios as low as 2 to 1 . These results suggested that the lysozyme release might be related to the degree of phagocytic activity since, at low ratios, T4 was readily ingested but T1 was not. Consistent with this hypothesis, serum which promoted the phagocytosis of the pilated gonococci also stimulated lysozyme release at low ratios of $\mathrm{T} 1$ to leucocyte. Absorption of the serum with $\mathrm{T} 1$ abolished the opsonic effect and markedly diminished the amount of lysozyme released.

\section{Introduction}

It is not clearly understood what properties of Neisseria gonorrhoeae contribute to the marked inflammation which accompanies acute gonorrhoea. Urethral smears from men with gonorrhoea typically show the gonococcus in association with polymorphonuclear leucocytes (PMN). Release of lysosomal contents from PMN has been implicated in tissue destruction during the inflammatory process (Ignarro, 1974). We wished to determine if the association of T1 with human leucocytes (WBC) would stimulate such release. We have investigated this possibility by incubating WBC with gonococci in vitro and examining the extracellular fluid for activity of the lysosomal enzymes, lysozyme, and $\beta$-glucuronidase ( $\beta G U)$ as well as for activity of the cytoplasmic enzyme-lactic acid dehydrogenase (LDH).

\footnotetext{
Address for reprints: L. M. Senff, Department of Microbiology, Indiana University School of Medicine, Indianapolis, Indiana 46202, USA

Received for publication 24 March 1977
}

\section{Materials and methods}

Types (T) 1 and $4 N$. gonorrhoeae, strain 2686, were serially subcultured as previously described on a solid medium (GCBI) containing GC medium (Difco) plus supplements (Thongthai and Sawyer, 1973). Clinical isolates of gonococci were cultured on GCBI from the urethral exudate of men suffering from acute gonorrhoea. For experiments, gonococci were grown on GCBI for 18 hours and harvested in $37^{\circ} \mathrm{C}$ broth having the same composition as GCBI less the agar and antibiotic. The bacteria were suspended in modified Hanks's solution with $0.01 \%$ bovine serum albumin (Armour) and $0.1 \%$ glucose (HBG) (Martin and Green, 1958). Bacteria were counted directly, and suspensions were diluted so that the required number of bacteria was contained in $0.05 \mathrm{ml}$.

WBC suspensions were prepared by dextran sedimentation of venous blood from volunteers denying a history of gonococcal infection (Thongthai and Sawyer, 1973). Suspensions contained $92 \pm$ $0.5 \%$ PMN. The high proportion of PMN in the suspensions suggests that the enzyme activity we recovered was largely from this cell type. Zurier $e t$ al. (1974) investigated enzymes of WBC suspensions 
containing only $83 \pm 4 \%$ PMN and found that the other cells (primarily monocytes and lymphocytes) contained less than $2 \%$ of the total $\beta G U$ and less than $10 \%$ of the total LDH.

Incubation of bacteria-WBC mixtures was in plastic tubes $(12 \times 75 \mathrm{~mm})$. WBC $\left(10^{7}\right)$ were suspended in $0.5 \mathrm{ml}$ of $\mathrm{HBG}$ plus $0.6 \mathrm{mmol} / 1 \mathrm{CaCl}_{2}$ and $1.0 \mathrm{mmol} / 1 \mathrm{MgSO}_{4}$. At zero time, bacteria were added and the tubes were tumbled end over end at $12 \mathrm{rev} / \mathrm{min}$ at $37^{\circ} \mathrm{C}$. After incubation $(0,30,60,90$, or $120 \mathrm{~min}$ ), mixtures were centrifuged at $950 \times g$ for 5 min at $4^{\circ} \mathrm{C}$ and the supernatants were removed, stored on ice, and assayed for enzyme activity within 24 hours.

BGU was determined with phenolphthalein glucuronide (Sigma) as substrate (Brittinger et al., 1968); lysozyme was determined by radial diffusion in agarose gel (Sigma) containing Micrococcus lysudeikticus (Osserman and Lawlor, 1966), and LDH was determined spectrophotometrically (Bergmeyer and Bernt, 1974).

Total enzyme activities were obtained by assay of supernatants from suspensions that were subjected to three cycles of freezing and thawing and the addition of triton $\times 100$ (Rohm and Haas Co.), final concentration $0.08 \%$. Typical totals for suspensions containing $10^{7} \mathrm{WBC} / 0.5 \mathrm{ml}$ were for $\beta \mathrm{GU}, 40 \cdot 1 \pm 1 \cdot 6 \mu \mathrm{g}$ phenolphthalein/h per $\mathrm{ml}$; for lysozyme, $25 \pm 1 \cdot 3 \mathrm{\mu g} / \mathrm{ml}$; and for $\mathrm{LDH}, 5 \cdot 9 \pm 0 \cdot 4$ optical density units/min per $\mathrm{ml}$. Comparison of enzyme totals for suspensions containing both bacteria and WBC with those for suspensions containing only WBC showed no significant difference in $\mathrm{LDH}$ or $\beta \mathrm{GU}$ activity at bacteria to WBC ratios as high as 50 to 1 . At low ratios of bacteria to WBC, lysozyme activity was not significantly different from that for WBC alone; at higher ratios, however, total lysozyme activity was slightly reduced. For experiments with the ratio of 50 to 1 , average total lysozyme activity was $22 \cdot 0 \pm$ $2 \cdot 3 \mu \mathrm{g} / \mathrm{ml}$ with bacteria and $\mathrm{WBC}$ and $27 \cdot 4 \pm 2 \cdot 0$ $\mu \mathrm{g} / \mathrm{ml}$ for WBC alone. This suggests that these bacteria may adsorb or deactivate lysozyme. We have not corrected for this effect but have used totals without bacteria to calculate percentage of enzyme released; at high ratios of bacteria to WBC, the actual percentage released would probably be somewhat higher.

For incubation mixtures with bacteria to WBC ratios up to 10 to 1 , phagocytosis was estimated by observing stained smears (Thongthai and Sawyer, 1973) and was reported as the percentage of 400 PMN containing at least one bacterium. Thin sections of WBC pellets stained with $5 \%$ uranyl acetate and a mixture of vanadyl sulphate and ammonium paramolybdate (Pease, 1964) were examined with a RCA-3G electron microscope.

Normal human serum was collected from healthy adults with no history of gonococcal infection. Serum was diluted $1: 16$ in HBG plus $0.6 \mathrm{mmol} / \mathrm{l}$ $\mathrm{CaCl}_{2}$ and $1.0 \mathrm{mmol} / \mathrm{l} \mathrm{MgSO}_{4}$. Serum absorbed with $2686 \mathrm{~T} 1$ was prepared as described by Punsalang and Sawyer (1973).

\section{Results and discussion}

The Table shows the release of $\mathrm{LDH}, \beta \mathrm{GU}$, and lysozyme from human WBC during $30 \mathrm{~min}$ of incubation with gonococci. Unless otherwise indicated, strain 2686 was used for these experiments. T1 did not elicit appreciable release of the cytoplasmic enzyme, LDH, even at the highest ratio of 50 bacteria per WBC. This finding suggests that contact with $\mathrm{T} 1$ for relatively short periods does not alter the WBC cell membrane so as to cause leakage of macromolecular cytoplasmic constituents.

Table Enzyme release from human leucocytes incubated $^{1}$ with pilated and non-pilated $\mathrm{N}$. gonorrhoea

\begin{tabular}{|c|c|c|c|c|c|}
\hline \multirow[b]{2}{*}{ Gonococci } & \multirow{2}{*}{$\begin{array}{l}\text { Ratio } \\
B A C \text { : } \\
W B C\end{array}$} & \multirow{2}{*}{$\begin{array}{l}\text { Phagocy- } \\
\text { tosis } \\
(\%)\end{array}$} & \multicolumn{2}{|c|}{$\begin{array}{l}\text { Percentage } \\
\text { released }^{2}\end{array}$} & \multirow{2}{*}{ enzyme } \\
\hline & & & $L D H$ & $\beta G U$ & \\
\hline T19 & $\begin{array}{r}5 \\
20 \\
50\end{array}$ & $\begin{array}{l}10 \dagger \\
\text { ND } \\
\text { ND }\end{array}$ & $\begin{array}{c}-0.3_{+}^{+} \\
-0.9 \\
0.9\end{array}$ & $\begin{array}{l}-0.2 \\
-0.4 \\
-0.8\end{array}$ & $\begin{array}{l}0 \cdot 5 \\
3 \cdot 9^{*} \\
6 \cdot 2^{*}\end{array}$ \\
\hline $\begin{array}{l}\text { Clinical } \\
\text { isolate } T 18\end{array}$ & $\begin{array}{r}5 \\
20 \\
50\end{array}$ & $\begin{array}{l}11 \\
\text { ND } \\
\text { ND }\end{array}$ & $\begin{array}{l}0.4 \\
1.4 \\
0.8\end{array}$ & $\begin{array}{l}1 \cdot 1 \\
3 \cdot 2^{*} \\
3 \cdot 0^{*}\end{array}$ & $\begin{array}{r}5 \cdot 1^{*} \\
13 \cdot 8^{*} \\
17 \cdot 4^{*}\end{array}$ \\
\hline T4S & $\begin{array}{r}1 \\
2 \\
5 \\
10\end{array}$ & $\begin{array}{r}5 \\
17 \\
45 \\
58\end{array}$ & $\begin{array}{r}-0.3 \\
0.1 \\
-0.7 \\
0.9\end{array}$ & $\begin{array}{c}-0.5 \\
0.5 \\
0.3 \\
2.6^{*}\end{array}$ & $\begin{array}{c}1 \cdot 6 \\
5 \cdot 3^{*} \\
10 \cdot 7^{*} \\
12 \cdot 9^{*}\end{array}$ \\
\hline $\begin{array}{l}\text { T1 with } \\
\text { normal } \\
\text { serum } \$ \\
\text { T1 with } \\
\text { absorbed } \\
\text { serum } \$\end{array}$ & 5 & 23 & 0.0 & $1 \cdot 4$ & $9 \cdot 2 *$ \\
\hline
\end{tabular}

1. Incubation time was $30 \mathrm{~min}$.

2. Enzyme values are corrected for spontaneous release as measured with control suspensions of WBC incubated without bacteria. The standard deviation of differences in duplicates was used to establish values significantly different from controls at the $95 \%$ confidence level; the appropriate values were for $\mathrm{LDH} \pm 3 \cdot 1 \%$, for $\beta G U \pm 2 \cdot 2 \%$, and for lysozyme $\pm 3.8 \%$. An asterisk indicates release which is significantly different from controls at $P \leqslant 0.05$.

†ercentage of 400 PMN containing at least one bacterium. For ratios of bacteria to WBC greater than 10 to 1 , the number of bacteria remaining associated with WBC precluded determination of extent of phagocytosis.

\$Negative values indicate samples with enzyme activity less than control; values for such samples were never significantly different from controls and never exceeded $0.9 \%$ total enzyme.

SResults of one representative experiment; for incubation mixtures containing serum we included normal human serum diluted 1:16. This dilution was chosen since higher concentration of serum sometimes led to clumping of WBC.

T Average of eight experiments with 2686. 
An appreciable release of the lysosomal enzyme, $\beta G U$, was not detected within $30 \mathrm{~min}$ (Table). Lysozyme, however, was released into the extracellular medium at bacteria to WBC ratios of both 20 to 1 and 50 to 1 . With longer incubation (120 min) at 50 to 1 , significant release of both enzymes occurred; the amount of lysozyme released $(22.6 \%)$ was greater than that of $\beta G U(8 \cdot 1 \%)$.

As strain 2686 has been in culture for several years, we also examined clinical isolates that had been passaged only three times on GCBI. The Table shows the effects of one of these isolates on enzyme release. The pattern was qualitatively similar to that found with strain 2686; neither LDH nor $\beta G U$ was released in large amounts in $30 \mathrm{~min}$, but lysozyme release was significant. Comparison of values for $2686 \mathrm{~T} 1$ with those for recent isolates suggests that the latter stimulate greater lysozyme release at lower ratios (Table). This may result either from properties of gonococci that are lost or diminished upon serial in vitro cultivation or from strain variation.

Although $\mathrm{T} 1$ are relatively resistant to phagocytosis (Thongthai and Sawyer, 1973), the extent of phagocytosis would be expected to increase as the ratio of bacteria to WBC increases (Clawson and Repine, 1976). Indeed, electron microscopical examination of thin sections of the WBC pellet from mixtures containing $50 \mathrm{~T} 1$ per $\mathrm{WBC}$ revealed many PMN with ingested cocci and marked degranulation. Such mixtures had a significant release of lysozyme $(6 \cdot 2 \%)$. At the ratio 5 to 1 , negligible enzyme release was found (Table) and typically only about $10 \% \mathrm{PMN}$ appeared to contain bacteria. Thus, the degree of phagocytic activity of WBC incubated with $\mathrm{T} 1$ may be important in the release of lysozyme.

To evaluate the effect of phagocytosis on enzyme release, we studied WBC incubated with T4, which are more readily ingested than $\mathrm{T} 1$ (Thongthai and Sawyer, 1973). The Table shows that the same qualitative pattern of enzyme release occurred with these bacteria as with T1. Little LDH or $\beta G U$ was released but a significant amount of lysozyme was found in the extracellular fluid. Comparison of the relative amounts of lysozyme released, however, showed that much lower numbers of bacteria were required to give $10 \%$ release if the bacteria were readily ingested. A ratio of 5 to 1 with T4 elicited such release, whereas a ratio of 50 to 1 was required with $\mathrm{T} 1$. These results are consistent with the idea that enzyme release into the extracellular environment may partly be a function of phagocytic activity.

In vivo, WBC encounter gonococci in tissue fluids that contain a variety of substances, some of which are derived from serum. To assess the effect of serum on enzyme release in the presence of gonococci, we included human serum diluted 1:16 in the incubation mixture (Table). The presence of serum enhanced the release of lysozyme but not of LDH or $\beta G U$. This effect was greatest with serum that increased phagocytosis but it was not entirely caused by opsonic effects, since serum that had been absorbed with $2686 \mathrm{~T} 1$ and did not opsonise also slightly enhanced lysozyme release.

PMN have both azurophilic granules (AG) and specific granules (SG) (Spitznagel, 1975); $\beta G U$ is primarily found in AG while lysozyme is found in both granule types (66\% in SG, $33 \%$ in AG). The source of extracellular lysozyme we detected is probably the SG since significant release of the AG enzyme, $\beta G U$, was seldom demonstrated (Table). Greater release of SG constituents than of AG substances has previously been demonstrated (Estensen et al., 1974; Leffell and Spitznagel, 1975).

Two recent investigations examined the effect of gonococci on PMN degranulation (Schultz and Thomas, 1975; Densen and Mandell, 1976). PMN myeloperoxidase (MPO) activity, as measured by the iodination procedure of Klebanoff (1967), was stimulated more by incubation with non-pilated gonococci than with T1. Iodination measures WBC-associated MPO rather than that released extracellularly and is an indication of degranulation of AG since $90 \%$ of MPO is associated with these granules (Spitznagel, 1975). These results (Schultz and Thomas, 1975; Densen and Mandell, 1976) taken together with ours suggest that short-term incubation of human WBC with gonococci does not bring about either marked degranulation or a significant release of granule enzymes unless conditions are used that favour ingestion of the bacteria (that is, nonpilated bacteria, opsonising serum, or high ratios of pilated gonococci to PMN).

While short-term in vitro incubation with $\mathrm{T} 1$ does not bring about substantial degranulation and release of PMN granule enzymes extracellularly, the in vivo contribution of these enzymes to the inflammation of gonorrhoea remains possible. Phagocytosis occurring in exudates of men suffering from acute gonococcal infection has been estimated to be as low as 5\% (Clarridge et al., 1976) and as high as $42 \%$ (Thongthai and Sawyer, 1973). Under in vitro conditions that encouraged phagocytic activity, we found extracellular discharge of the SG within $30 \mathrm{~min}$, and the addition of serum enhanced this effect (Table). If we prolonged the incubation period to $120 \mathrm{~min}$ for suspensions containing 50 T1 to WBC, we also found discharge of $\beta G U$ $(8.1 \%, \mathrm{P}<0.05)$. 
SG contain two antibacterial substances, lysozyme and lactoferrin, while AG contain a variety of hydrolytic enzymes (Spitznagel, 1975) including the neutral proteases previously shown to contribute to inflammation and connective tissue destruction (Ignarro, 1974). Thus, a short-term encounter between PMN and gonococci could bring about a twofold protective effect for the host: firstly, ingestion of bacteria, and secondly, the release of SG contents that could act on the bacteria remaining external to the WBC. On the other hand, prolonged interaction between the pathogen and PMN would also be likely to result in leakage of AG contents; these substances could potentially act not only on extracellular bacteria but on host tissues as well.

The authors gratefully thank R. S. Fulbright and A. E. Burrows for expert technical assistance and W. S. Wegener for helpful discussion. This investigation was supported in part by Public Health Service Grant ROI-AI-12087 and Public Health Service Institutional Research Fellowship Grant PHS T22 A100030-03 from the National Institute of Allergy and Infectious Diseases.

\section{References}

Bergmeyer, H., and Bernt, E. (1974). Lactic acid dehydrogenase. In Methods of Enzymatic Analysis, second edition, volume 2, p. 574. Edited by J. U. Bergmeyer. Academic Press: New York.

Brittinger, G., Hirschhorn, R., Douglas, S. D., and Weissman, G. (1968). Studies on lysosomes. XI. Characterization of a hydrolase rich fraction from human lymphocytes. Journal of Cell Biology, 37, 394-411.
Clarridge, J. E., Huber, T. W., and Williams, R. P. (1976). Neisseria gonorrhoeae in Male Exudate: Colony Type, Viability, and Degree of Leukocyte Association. Abstracts of National Meeting of the American Society for Microbiology, B85.

Clawson, C. C., and Repine, J. E. (1976). Quantitation of maximal bactericidal capability in human neutrophils. Journal of Laboratory and Clinical Medicine, 88, 316-327.

Depsen, P., and Mandell, G. L. (1976). Stimulation of neutrophil metabolism by adherent and ingested gonococci. Clinical Research, 24, $342 \mathrm{~A}$.

Estensen, R. D., White, J. G., and Holmes, B. (1974). Specific degranulation of human polymophonuclear leucocytes. Nature, 248, 347-348.

Ignarro, L. J. (1974). Regulation of lysosomal enzyme secretion: role in inflammation. Agents and Actions, 4, 241-258.

Klebanoff, S. J. (1967). Iodination of bacteria: A bactericidal mechanism. Journal of Experimental Medicine, 126, 1063-1078.

Leffell, M. S., and Spitznagel, J. K. (1975). Fate of human lactoferrin and myeloperoxidase in phagocytizing human neutrophils: Effects of immunoglobulin $\mathrm{G}$ subclasses and immune complexes coated on latex beads. Infection and Immunity, 12, 813-820.

Martin, S. P., and Green, R. (1958). Methods for the study of surviving leukocytes. A. Preparation of cell suspensions. Methods in Medical Research, 7, 136-138.

Osserman, E. F., and Lawlor, D. P. (1966). Serum and urinary lysozyme (muramidase) in monocytic and monomylelocytic leukemia. Journal of Experimental Medicine, 124, 921-952.

Pease, D. C. (1964). Histological Technique for Electron Microscopy, second edition, p. 242. Academic Press: New York.

Punsalang, A. P., and Sawyer, W. D. (1973). Role of pili in the virulence of Neisseria gonorrhoeae. Infection and Immunity, 8, 255-263.

Schultz, W. W., and Thomas, D. W. (1975). Effect of infection with gonococci on myeloperoxidase activity of leucocytes. British Journal of Venereal Diseases, 51, 170-173.

Spitznagel, J. K. (1975). Advances in the study of cytoplasmic granules of human neutrophilic polymorphonuclear leukocytes. In The Phagocytic Cell in Host Resistance, p. 77. Edited by J. A. Bellanti and H. Dayton. Raven Press: New York.

Thongthai, C., and Sawyer, W. D. (1973). Studies on the virulence of Neisseria gonorrhoeae. I. Relation of colonial morphology and resistance to phagocytosis by polymorphonuclear leukocytes. Infection and Immunity, 7, 373-379.

Zurier, R. B., Weissmann, G., Hoffstein, S., Kammerman, S., and Tai, H. H. (1974). Mechanisms of lysosomal enzyme release from human leukocytes. II. Effects of cAMP and cGMP, autonomic agonists, and agents which affect microtubule function. Journal of Clinical Investigation, 53, 297-309. 